International Journal of Wildland Fire 2012, 21, 86-92

http://dx.doi.org/10.1071/WF10108

\title{
Reconstructing fire history in central Mongolia from tree-rings
}

\author{
Amy E. Hessl ${ }^{\mathrm{A}, \mathrm{J}}$, Uyanga Ariya $^{\mathrm{B}}$, Peter Brown $^{\mathrm{C}}$, Oyunsannaa Byambasuren ${ }^{\mathrm{B}}$, \\ Tim Green ${ }^{\mathrm{D}}$, Gordon Jacoby ${ }^{\mathrm{E}}$, Elaine Kennedy Sutherland ${ }^{\mathrm{F}}$, \\ Baatarbileg Nachin ${ }^{\mathrm{B}}$, R. Stockton Maxwell ${ }^{\mathrm{G}}$, Neil Pederson, \\ Louis De Grandpré ${ }^{\mathrm{H}}$, Thomas Saladyga ${ }^{\mathrm{A}}$ and Jacques C. Tardif ${ }^{\mathrm{I}}$ \\ A Department of Geology and Geography, West Virginia University, Box 6300, Morgantown, \\ WV 26506, USA. \\ ${ }^{B}$ Department of Forest Sciences, National University of Mongolia, 14201 Ulaanbaatar \\ 46A/135, Mongolia. \\ C Rocky Mountain Tree Ring Research, 2901 Moore Lane, Fort Collins, CO 80526, USA. \\ D Department of Geography, University of Tennessee, Knoxville, TN 37996, USA. \\ ${ }^{\mathrm{E}}$ Tree-Ring Laboratory, Lamont-Doherty Earth Observatory, POB 1000, 61 Route 9W, \\ Palisades, NY 10964, USA. \\ FMissoula Forestry Sciences Laboratory, US Forest Service, 800 East Beckwith, Missoula, \\ MT 59801 USA. \\ GDepartment of Geography, Pennsylvania State University, University Park, PA 16802, USA. \\ ${ }^{\mathrm{H}}$ Canadian Forest Service, Laurentian Forestry Centre, 1055 du P.E.P.S, PO Box 10380, \\ Stn. Sainte-Foy, Québec, QC, G1V 4C7, Canada. \\ 'Centre for Forest Interdisciplinary Research (C-FIR), University of Winnipeg, Department of \\ Biology and Environmental Studies, 515 Avenue Portage, Winnipeg, MB R3B 2E9, Canada. \\ JCorresponding author. Email: amy.hessl@mail.wvu.edu
}

\begin{abstract}
Rising temperatures are expected to increase wildfire activity in many regions of the world. Over the last 60 years in Mongolia, mean annual temperatures have increased $\sim 2^{\circ} \mathrm{C}$ and the recorded frequency and spatial extent of forest and steppe fires have increased. Few long records of fire history exist to place these recent changes in a historical perspective. The purpose of this paper is to report on fire history research from three sites in central Mongolia and to highlight the potential of this region as a test case for understanding the relationships between climate change, fire and land use. We collected partial cross-sections from fire-scarred trees and stumps at each site using a targeted sampling approach. All three sites had long histories of fire ranging from 280 to 450 years. Mean Weibull fire return intervals varied from 7 to 16 years. Fire scars at one protected-area site were nearly absent after 1760, likely owing to changes in land use. There is limited synchrony in fire occurrence across sites, suggesting that fire occurrence, at least at annual time scales, might be influenced by local processes (grazing, human ignitions, other land-use factors) as well as regional processes like climate. Additional data are being collected to further test hypotheses regarding climate change, land use and fire.
\end{abstract}

Additional keywords: climate change, forest-steppe, land use.

Received 16 September 2010, accepted 2 May 2011, published online 16 November 2011

\section{Introduction}

Rising temperatures are expected to increase wildfire activity in many regions of the world (IPCC 2007). In Mongolia, mean annual temperatures have increased $\sim 2^{\circ} \mathrm{C}$ from 1940 to 2010 while spring precipitation has declined 17\% (Batima et al. 2005). Most of the warming has occurred in winter, potentially leading to earlier snowmelt and a longer growing season (De Grandpré et al. 2011). Mongolia has also experienced an increase in the frequency and intensity of droughts in the last three decades (Batima et al. 2005). These changes in climate may be associated with increases in the frequency and areal extent of forest and steppe fires observed over the last $\sim 50$ years (Goldammer 2002). However, a longer-term record of fire history is necessary to put recent changes in the fire regime into historical perspective, particularly within the context of landuse change. 


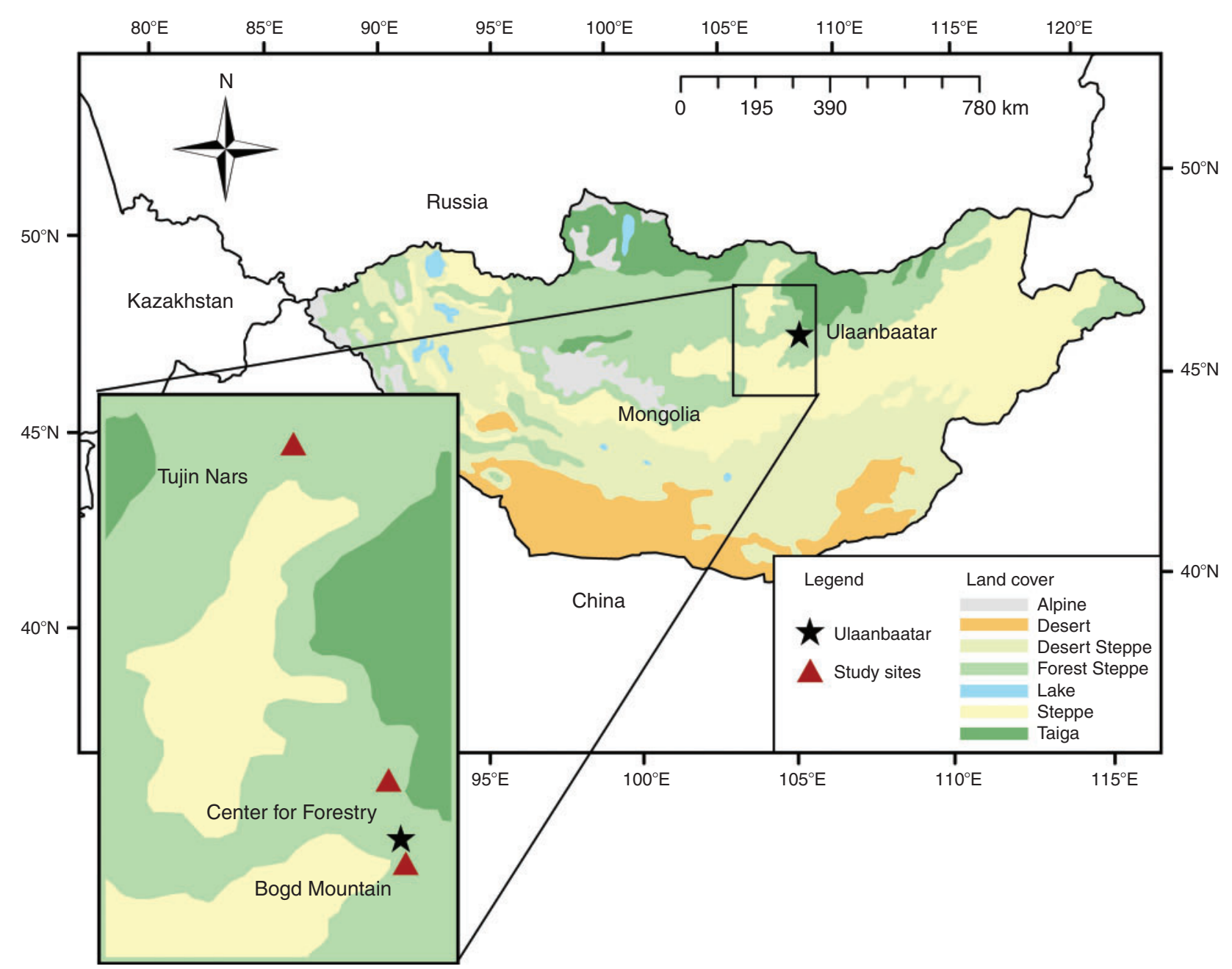

Fig. 1. Vegetation land cover in Mongolia and general location of study sites (rectangle) near Ulaanbaatar (black star). Inset includes Ulaanbaatar (black star) and the three study sites (red triangles).

Although Mongolia has not had an effective fire suppression policy, it has undergone a series of important land-use changes alongside climate change in the last 100 years. Livestock production has been Mongolia's dominant economic engine for millennia, but the intensity of pastoral land-use has varied over the last several centuries coincident with political and economic changes (Fernandez-Gimenez 2000). Mongolia's human population is currently 2.5 million whereas the livestock (camels, cattle, horses, sheep and goats) population exceeds 40 million (FAO 2010). Approximately one-third of the people in Mongolia practice pastoralism, although approximately half of the nation's population depends directly or indirectly on the pastoral economy for their livelihood (Fernandez-Gimenez 2000). As grazing intensity has varied over time, fine fuels undoubtedly varied as well, which might have affected the extent, timing and frequency of forest fires. Simultaneously, policies and regulations related to pastoralism and the use of non-timber forest products may have resulted in changes in fuels and human ignitions over time (Valendik et al. 1998; Wyss and Fimiarz 2006). These land-use changes have acted either independently or in concert with climate variability in affecting Mongolia's fire regimes.

Records of long-term variability in fire regimes and their associated drivers (e.g. climate, land use) can help place current fire regimes into a historical perspective and disentangle the effects of land use and climate change on fire. A range of paleoclimatic information has been collected in Mongolia (Jacoby et al. 1996; D'Arrigo et al. 2000, 2001; Pederson et al. 2001; Fowell et al. 2003; Davi et al. 2006, 2009; Prokopenko et al. 2007; Schwanghart et al. 2009; De Grandpré et al. 2011); however, little long-term fire history information exists to evaluate whether recent fire activity is historically anomalous. The purpose of this paper is to report on preliminary fire history research from three sites in central Mongolia and to highlight the potential of this region as a test case for understanding the relationships between fire, climate change and land use. Our results cover three major forest types in Mongolia (forest-steppe, taiga and pine woodlands) and include forests with long histories of intensive human land use (Bogd Khan Mountain) as well as those with more limited 
Table 1. Description of the three study sites including latitude (Lat.), longitude (Lon.), elevation (Elev.), number of sample points, number of live trees, number of stumps or logs, total number of dated scars (\#Scars), first ring and last ring for each fire history time series

\begin{tabular}{|c|c|c|c|c|c|c|c|c|c|c|c|}
\hline Site & Lat. & Lon. & Dominant species & Area sampled (ha) & Elev. (m) & Points & Live trees & Stumps, logs & \#Scars & First ring & Last ring \\
\hline Bogd & $47^{\circ} 48^{\prime}$ & $106^{\circ} 57^{\prime}$ & Larix sibirica & 60 & 1750 & 7 & 0 & 17 & 56 & 1550 & 2005 \\
\hline Center & $48^{\circ} 15^{\prime}$ & $106^{\circ} 53^{\prime}$ & L. sibirica & 40 & 1600 & 2 & 13 & 4 & 31 & 1660 & 2005 \\
\hline Tujin Nars & $50^{\circ} 04^{\prime}$ & $106^{\circ} 22^{\prime}$ & Pinus sylvestris & 60 & 760 & 4 & 20 & 14 & 239 & 1704 & 2009 \\
\hline Total & & & & 160 & & 13 & 33 & 35 & 326 & 1550 & 2009 \\
\hline
\end{tabular}

access (Forestry Research Center of the National University of Mongolia).

\section{Study area}

Mongolia is located in central Asia, bordered on the north by Russian Siberia and to the east and south by China (Fig. 1). Mongolia is characterised by an extremely continental climate. Mean monthly temperatures in central Mongolia range from approximately $-18^{\circ} \mathrm{C}$ in winter to $16^{\circ} \mathrm{C}$ in summer, though winter temperatures have been rising since the 1940s (Davagdorj and Mijiddorj 1996; Jacoby et al. 1996; Valendik et al. 1998). Total annual precipitation in Mongolia is low (252 mm) and peaks in summer when $\sim 72 \%$ of annual precipitation falls as rain (Davagdorj and Mijiddorj 1996). However, in the forested and mountainous areas of central and northern Mongolia, total annual precipitation is higher, ranging from 300 to $400 \mathrm{~mm}$ (Batima et al. 2005). Between 1940 and 2001, spring precipitation declined 17\% nationwide (Batima et al. 2005). More recently, between 1979 and 1995, precipitation has decreased $25 \%$ in May and increased 33\% in August, shifting the peak season of annual precipitation 1 month (Jacoby et al. 1996). The growing season extends from May to August. No single synoptic system strongly influences Mongolian climate except perhaps the winter Siberian High, which is centred over Mongolia from winter through late spring (Samel et al. 1999; D'Arrigo et al. 2005). Though decadal variability in drought exists (Pederson et al. 2001, Davi et al. 2006), it is of unknown cause.

Although most of Mongolia is either steppe or desert, approximately one-third of the country, mainly in the north, is forested. This ecotonal area is dominated by Larix sibirica (Ledep.), Pinus sibirica (Du Tour), P. sylvestris (L.) and Betula platyphylla (Sukaczev). Other important tree species present in the region include Populus tremula (L.), Picea obovata (Ledeb.) and Abies siberica (Ledeb.). As in other arid forests, fire regimes in central Mongolia are predominantly surface fires fuelled by fine grasses and woody fuels. Approximately $80 \%$ of fires occur in spring (Goldammer 2002) and $\sim 90 \%$ of fires are ignited by people (Wyss and Fimiarz 2006).

We compared fire history derived from fire-scarred trees from three sites (Table 1; Fig. 1): Bogd Khan Mountain (Bogd), Forestry Research Center of the National University of Mongolia (Center) and Tujin Nars. The sites are located along a 300-km north-south transect that extends along the transition zone between forest-steppe in the south at Bogd and boreal forest regions in the north near Tujin Nars.

Bogd Khan Mountain, located $15 \mathrm{~km}$ south of Ulaanbaatar and originally protected by Chinggis Khan in the 12th century, is one of the world's oldest officially protected areas (UNESCO World Heritage, see http://whc.unesco.org/en/tentativelists/ 936/, accessed 12 September 2011; De Grandpré et al. 2011). Though Bogd has been protected from logging for centuries, its proximity to the capital city indicates long-term intensive use for grazing and non-timber forest products. The Bogd site is dominated by Pinus sylvestris and $P$. sibirica, with occasional Larix sibirica and Betula platyphylla stands. The Center site, located $\sim 40 \mathrm{~km}$ north of Ulaanbaatar, does not have a history of protection and is representative of typical pine-larch forests in central Mongolia with moderate land use. Finally, Tujin Nars (Mongolian for 'always pine') is a monospecific stand of $P$. sylvestris located just south of the Russian border and is characterised by recent fires and post-fire logging beginning in the 1990s. Historical land-use of Tujin Nars is not known, but it is within $10 \mathrm{~km}$ of a border town (Sukhbaatar). Although Center and Tujin Nars have evidence of recent stand-replacing fire, Bogd does not. At Bogd, fire-scarred collections were primarily obtained from L. sibirica stumps under a canopy of mature $P$. sylvestris, whereas fire scar samples were collected from $P$. sylvestris and $L$. sibirica trees, snags, logs and stumps at Center. At Tujin Nars, samples were collected entirely from $P$. sylvestris logs, stumps and live trees.

\section{Methods}

Sampling was conducted in June 2006 (as part of the International Dendroecological Field Week), June 2007 and July 2009. A targeted sampling approach was used in all three areas to find the longest and most complete record of fire for each site. In targeted sampling, trees are selected based on the numbers of fire scars visible in fire-created 'catfaces' (Fig. 2; insets). At Bogd and Center, sampling of fire-scarred trees and stumps was conducted on mid- to upper-elevation slopes between 1700 and $1800 \mathrm{~m}$ above sea level. Approximate search areas were $\sim 60$ ha at seven locations for Bogd and $\sim 40$ ha at two locations for Center. At Tujin Nars, sampling occurred on small swales and ridges at lower elevations $(\sim 760 \mathrm{~m})$ within a total search area of $\sim 60$ ha at four locations. We searched each site for fire-scarred living trees, snags and stumps. Partial cross-sections of fire-scarred trees were collected with a chainsaw. Additional age structure and fire scar collections have been made in these and other stands throughout Mongolia to investigate fire severity; however, these data are not discussed here.

Samples were planed and sanded until individual cells were visible under magnification (600-1000-grit sandpaper). Fire scars were crossdated against both an existing master 


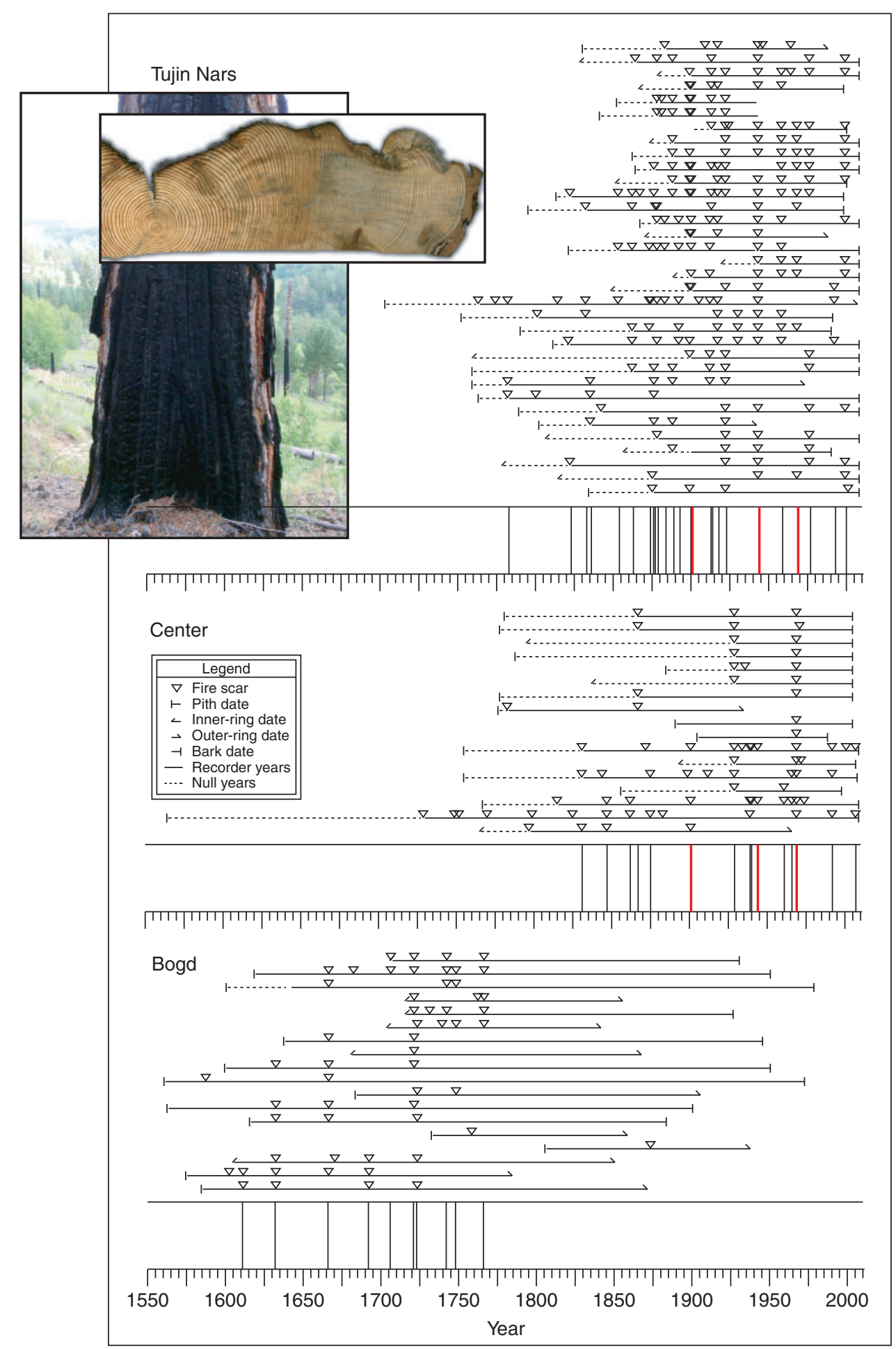

Fig. 2. Fire-scar chronologies from Tujin Nars, Center and Bogd. Horizontal lines mark time spans of individual fire-scarred trees. Inverted triangles indicate annually dated fire scars. Dashed lines represent periods between the inner ring date and the first fire scar. Pith and bark dates are indicated with a vertical tick. Slanted lines represent inner $(/)$ and outer $(\backslash)$ ring dates. Filtered fire scar events $(\geq 10 \%$ scarred and at least two trees) are noted with black vertical lines. Filtered fire events that are synchronous across sites (two or more) are noted with red vertical lines. Inset photos: a Scots pine (Pinus sylvestris) 'cat face' formed from repeated fire scars (black vertical ridges) and a partial cross-section from a $P$. sylvestris with multiple fire scars. 
Table 2. Fire regime summary including: number of intervals, median fire return interval (MFI), Weibull median fire interval (WMFI) and period from first filtered fire to last fire based on a filter of $\geq 10 \%$ scarred and at least two trees

\begin{tabular}{lcccc}
\hline Study site & \multicolumn{4}{c}{$\geq 10 \%$ scarred and at least two trees } \\
& Intervals & MFI & WMFI & Period \\
\hline Bogd & 9 & 17.2 & 15.8 & $1611-1766$ \\
Center & 14 & 12.6 & 10.7 & $1831-2007$ \\
Tujin Nars & 24 & 9.0 & 6.9 & $1783-2000$ \\
\hline
\end{tabular}

chronology derived from trees for the region (G. Jacoby, R. D. D'Arrigo and N. Pederson, 2009, International Tree Ring Data Bank, http://www.ncdc.noaa.gov/paleo/treering.html, accessed 12 September 2011) and locally developed skeleton-plot chronologies. The year and season of fire (if distinguishable) were recorded in $F H X 2$ for each fire scar observed in cross-section (Grissino-Mayer et al. 1995). Dormant-season fires were assigned to the spring of the following year because $\sim 80 \%$ of forest fires in Mongolia occur from March to June (Goldammer 2002). Fire regime characteristics (number of scars, sample depth, percentage scarred over time) were summarised for the entire period of record at each site and fire charts were created in FHX2 (Grissino-Mayer 2001). Fire-interval statistics for each site were calculated using a filter of $\geq 10 \%$ scarred and at least two trees. No clear changes in fire regimes were observed (e.g. no effect of fire suppression), so the entire period of record for each site was included in fire return interval statistics. Synchrony, the tendency for distant sites to record fires in the same year, was compared across sites and over time.

\section{Results}

All three sites had long histories of fire ( 450 years at Bogd, 350 years at Center and 280 years at Tujin Nars), though fire regimes at each site were distinct (Table 1; Fig. 2). At Bogd, fires were frequent before $\sim 1766$, with a Weibull median fire interval (WMFI) of 16 years (filtered data) (Table 2). After 1766, fire scars were nearly absent, even though a sample depth of $>10$ trees was maintained until 1900 (Fig. 2). At Center, fires occurred with similar frequency (filtered WMFI $=17$ years), but continued into the 20th century, with the most recent fire recorded by two or more trees occurring in 1969 (Fig. 2). Tujin Nars recorded the highest frequency of fires (filtered WMFI $=$ 7 years), and fire occurrences continued to the present, with the most recent fire recorded in 2002. At Bogd and Center, most fires occurred during the dormant or early growing season (90 and 95\%). The remaining fires occurred throughout the growing season. At Tujin Nars, $13 \%$ of fires occurred in the dormant season, $67 \%$ in the early growing season and $16 \%$ occurred during the late growing season. There was limited synchrony at annual scales in fire occurrence across sites. Owing to the fire history at Bogd and the lack of temporal depth at the other two sites, Bogd has no synchronous fire years with Center or Tujin Nars. Center and Tujin Nars have only 3 fire years in common: 1901, 1944 and 1969.

\section{Discussion and conclusions}

The record of fire history here highlights its historical role in Mongolia and indicates variation with latitude, elevation and forest type. Preliminary results indicated that ample fire history data exist in Mongolia through living fire-scarred trees, stumps and other material (Fig. 2, inset). Although Bogd experienced nearly complete fire cessation since the 1760 s, the other sites continued to experience fires to the present. Preliminary superposed epoch analysis (SEA; results not shown) comparing the filtered fire event dates identified here with independent reconstructions of climate from tree rings indicated that only fires at Tujin Nars occurred during drought years $(n=24$, $P<0.05)$. At both Bogd and Center, results from SEA suggest that fire years were not significantly drier during the fire year $(P>0.05)$, though the number of events was small $(n=9$ and $n=14$ respectively). Among the synchronous fire years, 1944 was a moderate drought year (growing season Palmer Drought Severity Index, PDSI $=-1.89$ ) and 1969 was wet (growing season PDSI $=2.59)$ (Dai et al. 2004). No reliable instrumental data exist for 1901 in Mongolia; however, central Asia experienced near-normal conditions during the 1901 growing season (Dai et al. 2004), though other studies in southern Siberia report a major fire year (Valendik et al. 1992).

The limited fire synchrony between all three sites and the inconsistent results of the SEA across sites suggest that human drivers of fire might have been important in Mongolian forests alongside climate. Land-use change, either via changes in grazing intensity (fuels) or via changes in human ignitions, might have resulted in the pattern of fire cessation we observed at Bogd and the limited synchrony we observed across sites. The presence of grazing altered or eliminated surface fire regimes in other arid forests (Weaver 1959; Savage and Swetnam 1990; Grissino-Mayer et al. 1995; Hobbs 1996; Mast et al. 1998) and this may have been the case at Bogd. The city of Ulaanbaatar was initially founded in 1639 and became the capital of Mongolia in 1778. Both developments must have been associated with increased human and livestock populations. Fuel wood gathering can reduce available fuels for fires and may have been an important influence on fires in the past. Because grazing by ungulates reduces the biomass of plants available for burning, ungulates can reduce the frequency, aerial extent and intensity of fires, particularly in systems fuelled by mid-storey grass (Hobbs 1996). Additional fire history sites at the forest-steppe ecotone with different human histories and livestock densities are required to fully evaluate this hypothesis. Historical management of Bogd may have also included laws prohibiting ignitions. Although Mongolians do not have a tradition of intentional burning, unintentional ignitions (originating from cooking or camping fires for example) in combination with dry spring conditions are thought to have caused recent peaks in fire activity (Nyamjav et al. 2007).

Fire frequencies for larch- and pine-dominated stands reported here are consistent with previous studies in southern Siberian forests (Valendik et al. 1992) but much shorter than those reported farther north (Arbatskaya and Vaganov 1997). The short fire return intervals at Tujin Nars are similar to those observed in other Pinus sylvestris stands on sandy soils (Vaganov et al. 1996; Ivanova et al. 2010). A sudden increase 
in area burned across Mongolia has been documented by fire atlas data (Goldammer 2002; Nyamjav et al. 2007) and is expected based on recent increases in temperature and decreases in moisture (Batima et al. 2005). However, with data from these three sites alone, there is not a visible, distinct increase in fire frequency in recent decades. This is consistent with results from the nearby Tuva region of Russia, where fire intervals have not changed for at least 300 years, though fire severity may be increasing (Ivanova et al. 2010). It may be that the number of sites reported here is too small to observe an increase in frequency or that drying conditions have actually reduced fuel continuity and fire occurrence (Hessl 2011; Krawchuk and Moritz 2011). Alternatively, fire frequency may have remained stable while fire severity (not measured here) has changed. Additional data and statistical tests will be required to determine whether recent fires are within the range of historical variability.

\section{Acknowledgements}

This research was inspired by the 7th International Dendrochronological Fieldweek held at Bogd Mountain in 2005. We thank all field assistants who volunteered their time to support Fieldweek (E. Oyunbilig, B. Ser-Od and N. Biligbaatar). Additional research was supported by grants from the American Center for Mongolian Studies to R. Stockton Maxwell and the National Science Foundation grant number DEB 0815021.

\section{References}

Arbatskaya MK, Vaganov EA (1997) Long-term variability of fire frequency and tree-ring growth in the middle taiga region of central Siberia. Russian Journal of Ecology 28, 291-297.

Batima P, Natsagdorj L, Gombluudev P, Erdenetsetseg P (2005) Observed climate change in Mongolia. Assessments of Impacts and Adaptations to Climate Change (AIACC) Working Paper 12. Available at http:// www.aiaccproject.org/working_papers/Working\%20Papers/AIACC_ WP_No013.pdf [Verified 8 November 2011]

D'Arrigo RD, Jacoby GC, Pederson N, Frank D, Buckley B, Nachin B, Mijiddorj R, Dugarjav C (2000) Mongolian tree-rings, temperature sensitivity and reconstructions of northern hemisphere temperature. The Holocene 10, 669-672. doi:10.1191/09596830094926

D’Arrigo RD, Jacoby GC, Pederson N, Frank D, Buckley B, Nachin B, Mijiddorj R, Dugarjav C (2001) 1738 years of Mongolian temperature variability inferred from a tree-ring width chronology of Siberian pine. Geophysical Research Letters 28, 543-546. doi:10.1029/ 2000GL011845

D'Arrigo RD, Jacoby GC, Wilson R, Panagiotopoulos F (2005) A reconstructed Siberian High index since AD 1599 from Eurasian and North American tree rings. Geophysical Research Letters 32, L05705. doi:10.1029/2004GL022271

Dai A, Trenberth KE, Qian T (2004) A global data set of Palmer Drought Severity Index for 1870-2002: relationship with soil moisture and effects of surface warming. Journal of Hydrometeorology $\mathbf{5}$ 1117-1130. doi:10.1175/JHM-386.1

Davagdorj D, Mijiddorj R (1996) Climate change issues in Mongolia. In 'Hydrometeorological Issues in Mongolia, Papers in Hydrometeorology'. (Eds D Davagdorj and L Natsagdorj) pp. 79-88 (Hydrometeorological Research Institute: Ulaanbaatar)

Davi NK, Jacoby GC, Curtis AE, Nachin B (2006) Extension of drought records for central Asia using tree rings: west-central Mongolia. Journal of Climate 19, 288-299. doi:10.1175/JCLI3621.1

Davi NK, Jacoby GC, D’Arrigo RD, Nachin B, Jinbao L, Curtis AE (2009) A tree-ring-based drought index reconstruction for far-western
Mongolia: 1565-2004. International Journal of Climatology 29, 1508-1514. doi:10.1002/JOC.1798

De Grandpré L, Tardif JC, Hessl A, Pederson N, Conciatori F, Green TR, Byambasuren O, Nachin B (2011) Seasonal shift in the climate response of Pinus sibirica, Pinus sylvestris and Larix sibirica trees from semi-arid, north-central Mongolia. Canadian Journal of Forest Research 41(6), $1242-1255$

FAO (2010) FAOSTAT. Food and Agriculture Organization of the United Nations. Available at http://faostat.fao.org/ [Verified 12 September 2011]

Fernandez-Gimenez ME (2000) The role of Mongolian nomadic pastoralists' ecological knowledge in rangeland management. Ecological Applications 10, 1318-1326. doi:10.1890/1051-0761(2000)010[1318: TROMNP]2.0.CO;2

Fowell SJ, Hansen BCS, Peck JA, Khosbayar P, Ganbold E (2003) Mid to late Holocene climate evolution of the Lake Telmen Basin, north central Mongolia, based on palynological data. Quaternary Research 59, 353-363. doi:10.1016/S0033-5894(02)00020-0

Goldammer JG (2002) Fire situation in Mongolia. International Forest Fire News 26, 75-83.

Grissino-Mayer HD (2001) FHX2 - software for analyzing temporal and spatial patterns in fire regimes from tree rings. Tree-Ring Research 57, 115-124

Grissino-Mayer HD, Baisan CH, Swetnam TW (1995) Fire history in the Pinaleño Mountains of South-eastern Arizona: effects of human-related disturbance. USDA Forest Service, General Technical Report, RM-GTR-264, pp. 399-407. (Fort Collins, CO)

Hessl AE (2011) Pathways for climate change effects on fire: models, data, and uncertainties. Progress in Physical Geography 35(3), 393-407.

Hobbs NT (1996) Modification of ecosystems by ungulates. The Journal of Wildlife Management 60, 695-713. doi:10.2307/3802368

Intergovernmental Panel on Climate Change (2007) 'Climate Change 2007 - the Physical Science Basis. Contribution of Working Group I to the Fourth Assessment Report of the Intergovernmental Panel on Climate Change, 2007.' (Eds S Solomon, D Qin, M Manning, Z Chen, M Marquis, KB Averyt, M Tignor, HL Miller) (Cambridge University Press: Cambridge, UK, and New York)

Ivanova GA, Ivanov VA, Kukavskaya EA, Soja AJ (2010) The frequency of forest fires in Scots pine stands of Tuva, Russia. Environmental Research Letters 5, 015002. doi:10.1088/1748-9326/5/1/015002

Jacoby GC, D'Arrigo RD, Davaajamts T (1996) Mongolian tree rings and 20th century warming. Science 273, 771-773. doi:10.1126/SCIENCE. 273.5276.771

Krawchuk MA, Moritz MA (2011) Constraints on global fire activity vary across a resource gradient. Ecology 92, 121-132. doi:10.1890/091843.1

Mast JN, Veblen TT, Linhart YB (1998) Disturbance and climatic influences on age structure of ponderosa pine at the pine/grassland ecotone Colorado Front Range. Journal of Biogeography 25, 743-755. doi:10.1046/J.1365-2699.1998.2540743.X

Nyamjav B, Goldammer JG, Uibrig H (2007) The fire situation in Mongolia International Forest Fire News 36, 46-66.

Pederson N, Jacoby GC, Cook ER, Buckley B (2001) Hydrometeorological reconstructions for north-eastern Mongolia derived from tree rings: 1651-1995. Journal of Climate 14, 872-881. doi:10.1175/1520-0442 (2001)014<0872:HRFNMD>2.0.CO;2

Prokopenko AA, Khursevich GK, Bezrukova EV, Kuzmin MI, Boes X, Williams DF, Fedenya SA, Kulagina NV, Letunova PP, Abzaeva AA (2007) Paleoenvironmental proxy records from Lake Hovsgol, Mongolia, and a synthesis of Holocene climate change in the Lake Baikal watershed. Quaternary Research 68, 2-17. doi:10.1016/ J.YQRES.2007.03.008

Samel AN, Wang WC, Liang XZ (1999) The monsoon rainband over China and relationships with the Eurasian circulation. Journal of Climate $\mathbf{1 2}$ 115-131. doi:10.1175/1520-0442-12.1.115 
Savage M, Swetnam TW (1990) Early 19th-century fire decline following sheep pasturing in a Navajo ponderosa pine forest. Ecology 71, 2374-2378. doi:10.2307/1938649

Schwanghart W, Frechen M, Kuhn NJ, Schütt B (2009) Holocene environmental changes in the Ugii Nuur basin, Mongolia. Palaeogeography, Palaeoclimatology, Palaeoecology 279, 160-171. doi:10.1016/ J.PALAEO.2009.05.007

Vaganov EA, Arbatskaya MK, Shashkin AV (1996) Climate history and fire incidence in the central part of Krasnoyarsk Krai. II. Dendrochronological analysis of relationship between variability of tree increment, climate, and fire incidence. Siberian Journal of Ecology 1, 19-27.
Valendik EN, Greybill DA, Ivanova GA, Shiyatov S (1992) Reconstruction of climatic changes and chronology of fires in mountain forests of southern middle Siberia. Lesovedenie 3, 34-40.

Valendik EN, Ivanova GA, Chuluunbator ZO (1998) Fire in forest ecosystems of Mongolia. International Forest Fire News 19, 58-63.

Weaver H (1959) Ecological changes in ponderosa pine forest of the Warm Springs Indian Reservation in Oregon. Journal of Forestry 57, 15-20.

Wyss D, Fimiarz M (2006) Forest fire mapping in Mongolia - the use of MODIS active fire products for strategic fire management. In 'Proceedings of the 27th Asian Conference on Remote Sensing', 9-13 October 2006, Ulaanbaatar, Mongolia. (Asian Association of Remote Sensing (AARS): Bangkok) 